\title{
Observations of the diurnal heating in the western equatorial Indian Ocean
}

Diurnal heating Surface heat exchange Western Indian Ocean Réchauffement diurne Échange thermique superficiel Océan Indien occidental

\author{
J.G. Bruce ${ }^{a}$, W.H. Beatty III ${ }^{b}$ \\ a Woods Hole Oceanographic Institution, Woods Hole, Massachusetts 02543, USA. \\ b US Naval Oceanographic Office, NSTL Station, Bay St-Louis, Mississippi 39522, USA.
}

Received $28 / 9 / 81$, in revised form $21 / 12 / 81$, accepted $28 / 12 / 81$.

\begin{abstract}
Observations in the northwest Indian Ocean during a windless, sunny day show an increase in the temperature at depths less than $5 \mathrm{~m}$ of 2 to $3^{\circ} \mathrm{C}$ above that of the upper

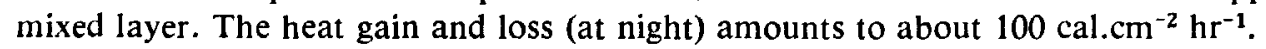

Oceanol. Acta, 1982, 5, 2, 137-139.

\section{RÉSUMÉ}

\section{Observations sur le réchauffement diurne dans l'Océan Indien ouest équatorial}

Des observations faites dans le nord-ouest de l'Océan Indien, par une journée ensoleillée et sans vent, ont mis en évidence, pour des profondeurs inférieures à $5 \mathrm{~m}$, des températures de 2 à $3^{\circ} \mathrm{C}$ plus importantes que celles de la couche supérieure de mélange. Le gain de chaleur (ou sa déperdition pendant la nuit) atteint environ $100 \mathrm{cal}$ $\mathrm{cm}^{-2} \mathrm{~h}^{-1}$.

Oceanol. Acta, 1982, 5, 2, 137-139.

During windless or near windless days with a relatively clear sky and strong insolation, the sea surface and a. thin layer (approximately 3 to $4 \mathrm{~m}$ ) below can become heated without being mixed downward by local winds. The incoming solar and outgoing longwave radiation cause a temperature change in the mixed layer. An optical path length of $1 \mathrm{~m}$ in the water absorbs approximately $64 \%$ of the solar energy, while $82 \%$ is absorbed in $10 \mathrm{~m}$ (Hoeber, 1972; Neumann, Pierson, 1966). Such a situation was examined by Bruce and Firing (1974) in the Atlantic by using expendable bathythermographs (XBTs) which were modified either to remain afloat for continuous sampling of the surface or to sink very slowly by attaching a jacket of styrofoam (part of XBT carton) around the probe. During the 1979 FGGE experiment in the Indian Ocean toward the end of the southwest monsoon aboard USNS "Wilkes" (operated by the US Naval Oceanographic Office) (Beatty et al., 1981) we encountered a somewhat similar set of conditions. On September 3 the wind appeared to be nearly zero in the afternoon as well as could be determined with the ship underway (as it was the entire time). An earlier observation during approximately mid-morning reported little wind and alternate bands of slick and small capillary waves, the spacing between bands being several ship lengths apart. The ship's course was about normal to the alignment of the bands. By mid-afternoon there was no indication of wind and a noted absence of capillary waves. The surface was glassy with a slight swell running. The sky was relatively clear throughout the daylight hours. Similar to the observations of Bruce and Firing (1974) an increase in the temperature of the upper few meters was observed during the day.

Standard XBT stations and bucket thermometer readings were taken hourly throughout and half hourly during the period of greatest warming. Surface temperature was sampled continuously with a through hull quartz thermometer (model 2801A Hewlett- 


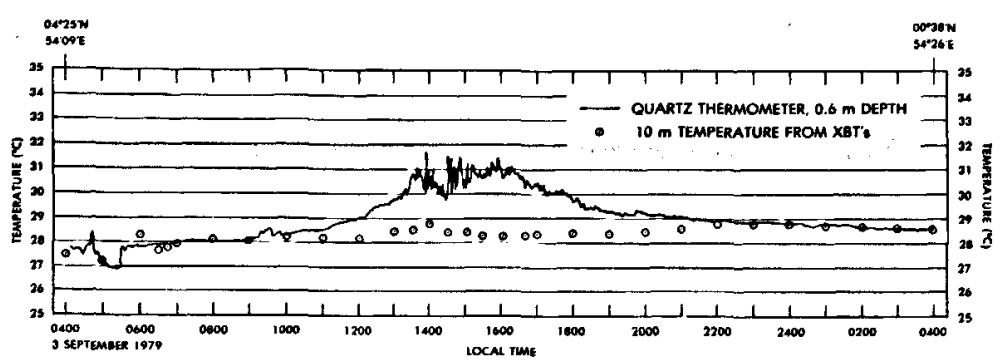

Figure 1

Temperature $\left({ }^{\circ} \mathrm{C}\right)$ from through-hull Hewlett-Packard $2801 \mathrm{~A}$ quartz thermometer and from XBT profiles depth $10 \mathrm{~m}, 3-4$ September 1979, USNS Wilkes.

Packard) at a depth of $60 \mathrm{~cm}$. Figure 1 shows that the quartz thermometer readings commenced to increase above the temperature at $10 \mathrm{~m}$ (from XBTs) after about $9 \mathrm{~h} 00$, local time, reaching the greatest range of values after $13 \mathrm{~h} 00$ which was maintained through about $16 \mathrm{~h} 00$ before starting to lose heat through back radiation. During the period of temperature increase small scale variations were relatively low amplitude but increased strongly after $13 \mathrm{~h} 00$ (see Fig. 1). It is not clear whether these features occurred as a surface manifestation of internal waves or by variations in the warming of the upper few meters. It is estimated that the apparent horizontal dimensions of the variations seen in Figure 1 would be on the order of 0.5 to $2 \mathrm{~km}$. The analogue temperature trace is given in more detail in Figure 2 where variations with as short a duration as

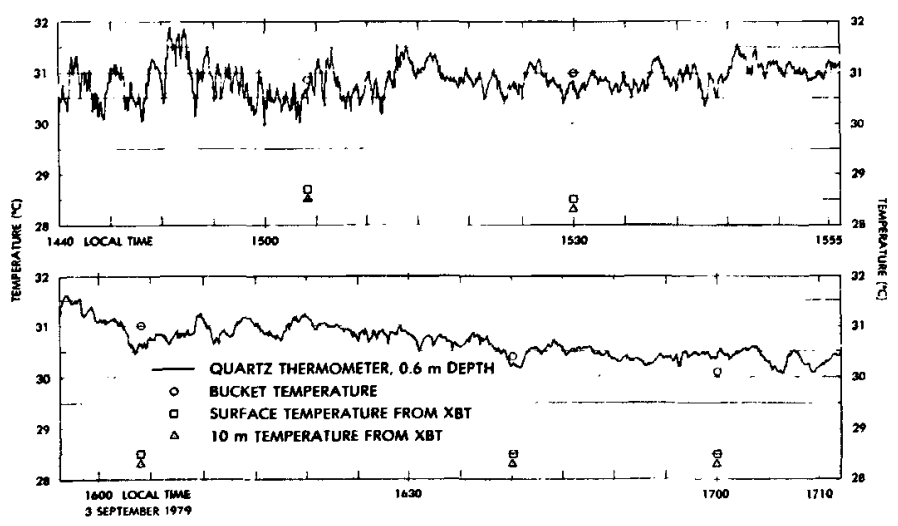

Figure 2

Details of surface and near surface temperature $\left({ }^{\circ} \mathrm{C}\right)$ from quartz thermometer, XBT profiles and bucket thermometer (USNS Wilkes, 3 September 1979) during period of greatest surface warming. Slow fall $X B T s$ were launched at $16 \mathrm{~h} 30$ and $16 \mathrm{~h} 45$.

$<30$ seconds are probably the result of ship's roll. At $16 \mathrm{~h} 30$ (Fig. 3) and $16 \mathrm{~h} 45$ two slow fall XBTs were launched with an estimated sinking rate of $0.15 \mathrm{~m} \mathrm{sec}^{-1}$ (rate determined by then launching a normal XBT probe). The warm near surface layer extended to approximately $4 \mathrm{~m}$ depth down to the top of the mixed layer. Several step-like layers $(10-20 \mathrm{~cm}$ thick) occur within this warm water with a thermal inversion lying between 1 to $2 \mathrm{~m}$ depth, possibly resulting from relatively high salinity caused by evaporation. The time required both to reach the high temperature range in Figure 1 and to cool back again to the temperature of the upper mixed layer at the end of the day is about five hours. If

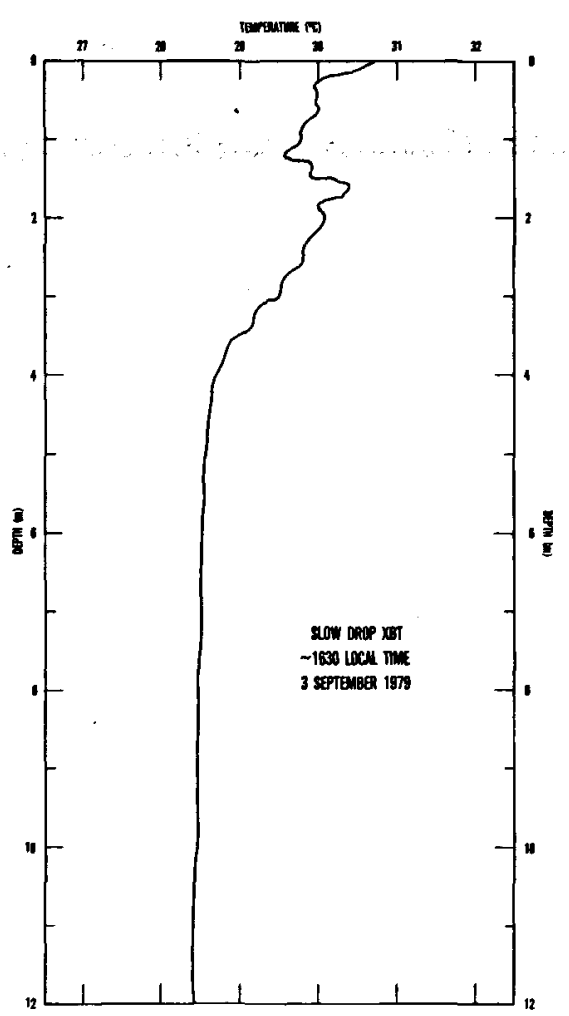

Figure 3

Temperature $\left({ }^{\circ} \mathrm{C}\right)$ profile of upper $12 \mathrm{~m}$ from slow fall $X B T$.

the temperature profile in Figure 3 is assumed to be typical, then a gain and loss rate of about $100 \mathrm{cal}^{\mathrm{cm}} \mathrm{cm}^{-2} \mathrm{hr}^{-1}$ might be expected (the same as the approximation in Bruce and Firing, 1974). It is suggested thus that the rate of heat accumulation by insolation and then by back radiation into the atmosphere is approximately the same during windless clear sky conditions such as these. This value is, of course, only a rough determination judging from the variability of the surface temperature record in Figures 1 and 2. It is somewhat greater than the values from Sverdrup et al.

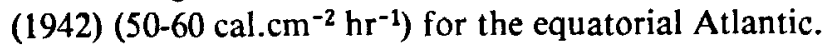
A considerably more detailed study would be required to arrive at an accurate value. It should be noted that a windless day in this region during the monsoon period is rare and was the only such day during the cruise.

It would appear that under such conditions the exchange processes tend to be limited to the upper few meters of the ocean, unlike conditions where a wind is present, in which case the thickness of this layer (termed the wave-mixed layer by Ostapoff, Worthern, 1974) would depend on wind speed (Woods, 1968; Leetmaa, Welch, 1972; Ostapoff et al., 1973). An experiment by Ostapoff and Worthern (1974) during which winds were typically $6-7 \mathrm{~m} \mathrm{sec}^{-1}$ showed considerably deeper penetration during the heating portion of the cycle into the diurnal thermocline layer at a rate of about $5 \mathrm{~m}$ $\mathrm{hr}^{-1}$. Although the mixed layer tended to become stabilized, turbulent exchange was able to influence water as deep as $30 \mathrm{~m}$ or more which approached the top of the main thermocline. Once this level is reached it becomes possible for dynamical processes within the thermocline to redistribute heat on a horizontal scale. 
However during the conditions of approximately zero wind as in our experiment, the penetration is limited due to the extreme stability occurring within the upper $5 \mathrm{~m}$ (with vertical gradients as much as $1^{\circ} \mathrm{C}$ per meter, whereas during the conditions with wind mixing in Ostapoff and Worthern the maximum gradient appears to be about $0.1^{\circ} \mathrm{C}$ per meter). Thus in the absence of wind most of the energy from the daytime heating would be returned to the atmosphere at night without reaching the thermocline where the horizontal advection could occur. It should be pointed out that our experiment was set up rather quickly at sea when it was noticed that the wind had stopped. Ideally it should be carried out from a small craft (such as a Zodiac raft which would disturb the near surface water as little as possible) and a number of slow fall XBT drops should be made during both the daylight and nighttime heat exchange process.

\section{Aknowledgements}

Support for this work by the Office of Naval Research under Contract N00014-79-C-0071, NR 083-004 is gratefully acknowledged.

\section{REFERENCES}

Beatty W.H., Bruce J.G., Guthrie R.C., 1981. Circulations and oceanographic properties in the Somali Basin during the 1979 southwest monsoon, Tech. Rep. NOO TR-258, US Naval Oceanographic Office, NSTL Station, Bay St. Louis, MS 39522.

Bruce J.G., Firing E., 1974. Temperature measurements in the upper $10 \mathrm{~m}$ with modified XBT probes, J. Geophys. Res., 79, 27 , 4110-4111.

Hoeber H., 1972. Eddy thermal conductivity in the upper $12 \mathrm{~m}$ of the tropical Atlantic, J. Phys. Oceanogr., 2, 3, 303-304.

Leetmaa A., Welch C.S., 1972. A note on diurnal changes in momentum transfer in the surface layers of the ocean, J. Phys. Oceanogr., 2, 302-303.
Neumann G., Pierson W.J., 1966. Principals of physical oceanography, Prentice-Hall, Inc., Englewood Cliffs, N.J., 545 p. Ostapoff F., Worthern S., 1974. The intradiurnal temperature variation in the upper ocean layer, J. Phys. Oceanogr., 4, 601-612.

Ostapoff F., Tarbeyev Y., Worthern S., 1973. Heat flux and precipitation estimates from oceanographic observations, Science, $180,960-962$.

Sverdrup H.U., Johnson M.W., Fleming R.H., 1942. The oceans, their physics, chemistry and general biology, Prentice-Hall, Englewood Cliffs, N.J., $1087 \mathrm{p}$.

Woods J.D., 1968. An investigation of some physical processes associated with the vertical flow of heat through the upper ocean, Meteor. Mag., 97, 65-72. 